\title{
LYDERYSTE் VISUOMENĖS SVEIKATOS STUDIJOSE: LIETUVOS VISUOMENĖS SVEIKATOS STUDENTŲ NUOMONĖS TYRIMAS
}

\author{
VITALIJA ZAJANČKAUSKIEN $\dot{E}^{1}$, MINDAUGAS STANK $\bar{N}$ AS $^{1,2}$ \\ ${ }^{l}$ Lietuvos sveikatos mokslu universiteto Sveikatos vadybos katedra, \\ ${ }^{2}$ Griffito universitetas, Gold Coast, Australija
} Raktažodžiai: visuomenès sveikatos specialistas, kompe-
tencijos, lyderyste்.

\begin{abstract}
Santrauka
Darbo tikslas - jvertinti visuomenés sveikatos bakalauro programos studenty nuomonę apie lyderystès studiju poreiki. Tyrimo metodika. Lietuvos visuomenés sveikatos bakalauro studiju programos trečio ir ketvirto kurso studentai buvo apklausti 2011 metais. Apklausa buvo vykdoma Lietuvos sveikatos mokslu, Vilniaus bei Klaipedos universitetuose. Tyrimo metu buvo išdalintos 187 anonimines anketos (atsako dažnis 93,0 proc), i kuria be specialiu uždaruju klausimu buvo ịtraukti ir atviri klausimai. Rezultatai. Tyrimas atskleide, kad visuomenés sveikatos bakalauro studiju programos studentai norètu mokytis lyderystès. Daugiau kaip pusè (53,4 proc.) visuomenés sveikatos bakalauro studiju programos studentu nurode, kad neturi lyderystes dalyko studiju programoje ir 54,9 proc. iš ju norètu, kad šis kursas bütu itrauktas i studiju programa. Dauguma (86,8 proc.) studentu mane, kad norint tapti geru visuomenes sveikatos specialistu reikia turèti gerus lyderystès igūdžius. Taip pat 63,8 proc. atsake, jog lavinti lyderystès igūdžius yra taip pat svarbu kaip tobulintis visuomenès sveikatos srityje. Studentai labiausiai norèjo, jog i lyderystès mokymus būtu ìtrauktos šios temos: „, Konfliktu sprendimo igūdžiai“, „Praktiniu bendravimo igūdžiu formavimas“ bei „Lyderyste komandineje veikloje“. Išvados. Visuomenes sveikatos bakalauro studiju programos studentai mano, kad lyderystès igūdžiai yra būtini visuomenès sveikatos praktikoje ir norètu, jog i ju studiju programa būtu ìtrauktas lyderystès dalykas.
\end{abstract}

\section{IVADAS}

Visuomenès sveikatos (VS) problemos ir iššūkiai sveikatai keičiasi priklausomai nuo kintančios fizinès, socialinès, ekonominès aplinkos. Pokyčių išvengti neįmanoma, o tam, kad juos būtų galima valdyti, reikia aukštos profesinès kompetencijos visuomenès sveikatos specialistų, gebančių formuoti ir igyvendinti aktyvią sveikatos politiką, itraukiant ị sveikatinimo veiklą visus sektorius [1-3]. Todèl nuolat auganti ,visuomenès sveikata“ reikalauja vis naujesnių kompetencijų [4].

Reaguojant ị sveikatos sistemos pokyčius atsiranda būtinybè keisti sveikatos specialistų paruošimą, kad jie būtų pasirengę naujiems iššūkiams ir ịsipareigojimams. Tas ypač svarbu visuomenès sveikatai, kuriai tiesiog būtina žmogiškujų išteklių plètra bei nuolatinis specialistų mokymas [1, $5,6]$. Be daugelio profesinių igūdžių, visuomenès sveikatos specialistai turi gebèti stiprinti ir palaikyti tarpsektorini bei intersektorinį bendradarbiavimą, skatinti koalicijų sudarymo ir partnerystès veiklas. Tas sąlygoja, kad auga lyderių, turinčių viziją ir gebančių ją puoselèti, poreikis [7-9].

Daugumai lyderyste vis dar siejasi su vadovu ir vadovavimu, tačiau šiuolaikinis požiūris pabrezžia lyderystės svarbą visuose organizacijos lygiuose. Tai grindžiama keletu priežasčių, iš kurių viena yra efektyvesnis žmogiškųjų išteklių - pagrindinio organizacijų konkurencinio pranašumo šaltinio -panaudojimas [10]. Aiškinama tuo, kad nuolatinés kaitos sąlygomis vadovai ne visada gali būti teigiamų pokyčiu iniciatoriais, nes tik patys darbuotojai geriausiai žino, kas jų darbą gali palengvinti ir padaryti efektyvesni $[11,12]$. Tai skatina suvokimą, kad lyderystè turètų būti ugdoma ir tarp organizacijos vadovų, ir tarp kitų organizacijos narių.

Lyderystès svarba bei lyderiu poreikis pabrěžiamas ir Pasaulio sveikatos organizacijos strateginiuose dokumentuose, kuriuose lyderyste ịvardijama kaip sprendimas naujiems sveikatos sistemos iššūkiams [13], kaip gerai funkcionuojančios sveikatos sistemos komponentas [14].

Lyderystės problematika mokslo tyrimuose yra labai populiari. Lyderytės fenomenui aprašyti sukurtos teorijos dažniausiai akcentuoja jos esmę bei svarbą organizacijų valdyme, o tai lemia lyderystès sampratos siaurumą, tapatinimą su aukštais postais bei pareigomis $[12,15]$. Todèl lyderystės mokymai dažniausiai skirti vadovams ar vadybininkams [8, 16-18]. Tačiau traktuojant lyderystę kaip kompetenciją, ji gali būti svarbi ne tik valdant organizacijas, bet visuose lygiuose.

Ivertinus aukšiau paminètas priežastis, lyderystès mo- 
kymas vis plačiau įtraukimas ị VS studijas. Tokie mokymai plačiai taikomi Jungtinèse Amerikos Valstijose. Panašios tendencijos pastebimos Australijos bei Jungtinès Karalystès universitetuose, kur ị VS studijų programas, atsižvelgiant ị tarptautinių VS rengimą koordinuojančių organizacijų rekomendacijas, ịtraukiamas ir lyderystès kursas [19, 20].

Nors lyderystès svarbą visuomenès sveikatoje pabrèžia nemažai jau aptartų autorių bei jos studijos yra organizuojamos kitų šalių universitetuose, Lietuvoje lyderystès mokymai visuomenès sveikatos studijų programose nèra

1 lentelė. Respondentụ pasiskirstymas pagal socialines ir demografines charakteristikas

\begin{tabular}{|c|c|c|}
\hline Socialiniai - demografiniai rodikliai & $\mathbf{n} /(\bar{x})$ & Proc./(SN) \\
\hline \multicolumn{3}{|l|}{ Lytis } \\
\hline Moterys & 153 & 87,9 \\
\hline Vyrai & 21 & 12,1 \\
\hline \multicolumn{3}{|l|}{ Amžius } \\
\hline 20 & 14 & 8,0 \\
\hline 21 & 100 & $\mathbf{5 7 , 5}$ \\
\hline 22 & 50 & 28,7 \\
\hline 23 ir daugiau & 10 & 5,8 \\
\hline Amžiaus vidurkis $(\bar{x} \pm \mathrm{SN})$ & $(21,33)$ & $(0,723)$ \\
\hline \multicolumn{3}{|l|}{ Universitetas } \\
\hline Klaipėdos & 47 & 27,0 \\
\hline Lietuvos sveikatos mokslu & 56 & 32,2 \\
\hline Vilniaus & 71 & 40,8 \\
\hline \multicolumn{3}{|l|}{ Kursas } \\
\hline III & 92 & 52,9 \\
\hline IV & 82 & 47,1 \\
\hline
\end{tabular}

n-respondentų skaičius; $\bar{X}$ - vidurkis; proc. -procentai; $S N$-standartinis nuokrypis

2 lentelè. Visuomenės sveikatos specialistų nuomonès apie lyderystę vertinimo kategorija „Lyderystės samprata“

\begin{tabular}{|c|c|c|}
\hline $\begin{array}{l}\text { Subkategorijos } \\
\text { (lyderystės sąvokai } \\
\text { priskiriamas } \\
\text { reikšminis vienetas) }\end{array}$ & Empirinių indikatorių (teiginių) pavyzdžiai & $\begin{array}{l}\text { Reikšminių vie- } \\
\text { netų teiginiuose } \\
\text { pasikartojimo } \\
\text { dažnis }\end{array}$ \\
\hline $\begin{array}{l}\text { 1. Lyderysté - } \\
\text { vadovavimas }\end{array}$ & $\begin{array}{l}\text { „Lyderystė - tai vadovavimas, tai mokèjimas } \\
\text { vadovauti“ }\end{array}$ & 42 \\
\hline $\begin{array}{l}\text { 2. Lyderystė - } \\
\text { pasekëjai }\end{array}$ & $\begin{array}{l}\text { „Lyderystė - kai grupé žmonių, komanda } \\
\text { veikia kartu“. }\end{array}$ & 5 \\
\hline $\begin{array}{l}\text { 3. Lyderystè - } \\
\text { itakojimas }\end{array}$ & $\begin{array}{l}\text { „Lyderystè - tai mokèjimas įkvèpti, motyvuoti } \\
\text { kitus“ }\end{array}$ & 3 \\
\hline $\begin{array}{l}\text { 4. Lyderystė - } \\
\text { asmeninès savybès }\end{array}$ & $\begin{array}{l}\text { "Lyderystè - tai savybė, kuomet išsiskiri iš kitu } \\
\text { savo sugebėjimais, savo drąsa, išskirtinumu, } \\
\text { protu“. }\end{array}$ & 18 \\
\hline $\begin{array}{l}\text { 5. Lyderysté - bendras } \\
\text { tikslas }\end{array}$ & „Lyderystè - bendro tikslo siekimas“. & 1 \\
\hline $\begin{array}{l}\text { „Etikečių“" } \\
\text { kombinacija: } 1 \text { ir } 2\end{array}$ & $\begin{array}{l}\text { Lyderystè - tai vadovavimas komandai, grupei } \\
\text { žmoniu““ }\end{array}$ & 22 \\
\hline $\begin{array}{l}\text { "Etikečių“" } \\
\text { kombinacija: } 1 \text { ir } 5\end{array}$ & $\begin{array}{l}\text { „Lyderystè - tai vadovavimas siekiant bendro } \\
\text { tikslo“. }\end{array}$ & 8 \\
\hline $\begin{array}{l}\text { „Etikečių“ } \\
\text { kombinacija: } 1 \text { ir } 2 \text { ir } 5\end{array}$ & $\begin{array}{l}\text { "Lyderystè - tai vadovavimas grupei žmonių } \\
\text { siekiant bendro tikslo“. }\end{array}$ & 6 \\
\hline $\begin{array}{l}\text { Reikšminių vienetų } \\
\text { kombinacija, } \\
\text { kurioje nėra etiketès } \\
\text { „vadovavimas“ }\end{array}$ & $\begin{array}{l}\text { „Lyderystė - tai sugebèjimas ịkvėpti ir } \\
\text { motyvuoti komandos narius siekiant bendro } \\
\text { tikslo“, „Lyderystė - tai nepriverstinės ịtakos } \\
\text { panaudojimas kitiems, gerai suvokiamos } \\
\text { vizijos turèjimas, pasitikėjimo ugdymas } \\
\text { kolektyve ir efektyvūs veiksmai siekiant } \\
\text { bendro tikslo“. }\end{array}$ & 16 \\
\hline
\end{tabular}

Pastaba: iš viso buvo pateikta 171 lyderystès apibrëžimas, t.y. 98,2 proc. atsakymų; lenetelëje pateiktas 131 (76,6proc.) atvejis, kuriame paminètas nors vienas reikšminis vienetas dažni. Kiek autoriams yra žinoma, atskirus lyderystès kursus (bakalauro bei magistro sudijų programose) šiuo metu siūlo tik Lietuvos sveikatos mokslų unviersitetas. Remiantis jau išsakytais argumentais, lyderystès mokymas turetu tapti kiekvienos visuomenės sveikatos studijų programos dalimi. Tačiau mūsų manymu, prieš teikiant pasiūlymus aukštujų mokyklų vadovybèms dèl šio kurso įtraukimo, tikslinga ivvertinti pačių studentų nuomonę šiuo klausimu. Deja, mokslinių darbų, kuriuose būtų analizuojama būsimų visuomenès sveikatos specialistų nuomonè apie lyderystès studijų poreikį, neaptikome.

Šio straipsnio tikslas - įvertinti visuomenès sveikatos bakalauro programos studentų nuomonę apie lyderystès studijų poreiki.

\section{TYRIMO MEDŽIAGA IR METODAI}

Vienmomentiné anoniminé anketiné apklausa buvo atlikta 2011 metais rugsèjo - lapkričio mènesiais. Apklausos metu buvo siekiama išsiaiškinti visuomenès sveikatos bakalauro programos studentų (VSBS) nuomonę apie lyderystès studiju poreikị. Lietuvoje visuomenès sveikatos krypties pirmosios pakopos studiju programas vykdo keturi universitetai - Lietuvos sveikatos mokslų universitetas (LSMU), Lietuvos kūno kultūros akademija (LKKA), Vilniaus universitetas (VU) ir Klaipedos universitetas (KU), kurie teikia visuomenès sveikatos bakalauro kvalifikacini laipsnį. Tačiau LKKA studijų programa skiriasi ne tik studijų programos pavadinimu, bet ir programos turiniu, kuris labiau orientuotas ị fizinio aktyvumo skatinimą. Taip pat, remiantis Higienos instituto duomenimis, visuomenés svei-

3 lentelè. Respondentų (neturẻjusių lyderystės kurso) nuomonès pasiskirstymas pagal tai, ar jie norètų, kad ị jų studijų programą būtụ įtrauktas lyderystės mokymas priklausomai nuo universiteto

\begin{tabular}{|c|c|c|c|c|}
\hline \multirow[t]{2}{*}{ Teiginys } & \multicolumn{3}{|c|}{ Universitetas } & \multirow{2}{*}{$\begin{array}{l}\text { Iš viso } \\
\text { n/proc. }\end{array}$} \\
\hline & $\begin{array}{c}\text { KU } \\
\text { n/proc. }\end{array}$ & $\begin{array}{l}\text { LSMU } \\
\text { n/proc. }\end{array}$ & $\begin{array}{c}\text { VU } \\
\text { n/proc. }\end{array}$ & \\
\hline Norėčiau & $24 / 51,5$ & $7 / 77,8$ & $20 / 54,1$ & $51 / 54,8$ \\
\hline Labiau kad norėčiau & $14 / 29,8$ & $1 / 11,1$ & $13 / 35,1$ & $28 / 30,1$ \\
\hline Labiau kad nenorėčiau & $8 / 17,0$ & $0 / 0$ & $3 / 8,1$ & $11 / 11,8$ \\
\hline Nenorèčiau & $1 / 2,1$ & $1 / 11,1$ & $1 / 2,7$ & $3 / 3,2$ \\
\hline Iš viso & $47 / 100$ & $9 / 100$ & $37 / 100$ & $93 / 100$ \\
\hline
\end{tabular}

n- tiriamuju skaišius; proc - procentai; lls - laisvès laipsniu skaičius; p - reikšmingumo lygmuo

4 lentelè. Respondentụ nuomonès pasiskirstymas pagal tai, ar lyderystès dalykas turètų būti privalomas VSBS programoje priklausomai nuo universiteto

\begin{tabular}{|l|c|c|c|c|}
\hline \multirow{2}{*}{ Teiginys } & \multicolumn{3}{|c|}{ Universitetas } & Iš viso \\
\cline { 2 - 4 } & $\begin{array}{c}\text { KU } \\
\text { n/proc. }\end{array}$ & $\begin{array}{c}\text { LSMU } \\
\text { n/proc. }\end{array}$ & $\begin{array}{c}\text { VU } \\
\text { n/proc. }\end{array}$ & \\
\hline Taip, turètų būti privalomas dalykas & $18 / 38,3$ & $35 / 62,5$ & $43 / 60,6$ & $96 / 55,2$ \\
\hline Ne, turètų būti pasirenkamas dalykas & $24 / 51,1$ & $20 / 35,7$ & $22 / 31,0$ & $66 / 37,9$ \\
\hline $\begin{array}{l}\text { Nemanau, kad toks dalykas yra reika- } \\
\text { lingas }\end{array}$ & $5 / 10,6$ & $1 / 1,8$ & $6 / 8,5$ & $12 / 6,9$ \\
\hline Iš viso: & $47 / 100$ & $56 / 100$ & $71 / 100$ & $174 / 100$ \\
\hline \multicolumn{2}{|r|}{} & & & \\
\hline
\end{tabular}
Pirsono chi-kvadratas $\left(\chi^{2}\right)=9,781 ;$ lls $=4 ; \mathrm{p}=0,044 ; \mathrm{p}<0,05$.

Pastaba: n-tiriamuju skaičius; proc. - procentai; $c^{2}$ - suderinamumo kriterijus; lls - laisvés laipsnių skaičius; * proc. nurodyta nuo visų atsakiusių $i$ ṣ̨̌ klausimq 


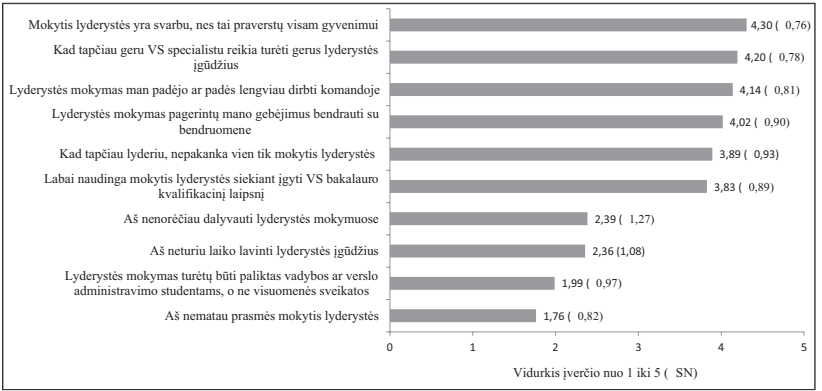

1 pav. Respondentų nuomonès pasiskirstymas pagal nurodytus teiginius $\bar{x}(\mathrm{SN})$.

Pastaba: $\bar{X}$ - vidurkis; $S N$-standartinis nuokrypis; kuo didesnè vidurkio reikšmé, tuo teiginys svarbesnis, kadangi koduota nuo 1 iki 5, kai 1 - visiškai nesutinku ir 5 - visiškai sutinku

katos priežiūrą vykdančių specialistų dauguma specialybę igijo LSMU, VU, KU [21], todèl tyrimui buvo pasirinkti būtent šie universitetai.

Anketos buvo dalinamos visiems LSMU, VU bei KU trečio ir ketvirto kurso visuomenès sveikatos studijų programos studentams. Iš viso buvo išdalinta 187 anketos, grąžinta - 174 (atsako dažnis 93,0 proc.). Tyrimo dalyvių pasiskirstymas pagal pagrindines demografines, socialines ir ekonomines charakteristikas pateikiamas 1 lenteleje.

Kiekybinè duomenų analizė buvo atliekama SPSS (angl. Statistical Package for Social Science) statistiniu paketu, versija 17.0. Hipotezès apie požymių priklausomumą bei nepriklausomų imčių vidurkių lygybę tikrintos naudojant Pirsono chi-kvadrato $\left(\chi^{2}\right)$, Mano-Vitnio ir KruskaloVoliso kriterijus. Pasirinktas reikšmingumo lygmuo - 0,05.

Remiantis kokybinio tyrimo metodologija buvo atlikta atvirų klausimų kokybinè turinio analizè. Duomenys buvo kategorizuojami: sakinio dalims suteikiami prasminiai vienetai - „etiketès“. Prie kiekvieno prasminio vieneto (,etiketès") pridedami pavyzdžiai.

\section{TYRIMO REZULTATAI IR JU ANALIZE்}

Siekiant ịvertinti VS specialistų nuomonę apie lyderystės studijų poreiki pirmiausia norejome sužinoti, kaip būsimi VS specialistai suvokia, kas tai yra lyderystè. Kadangi tyrimo objektas nuomoné, pateikème atvirą klausimą palikdami galimybę ją išsakyti ịrašant apibrěžimą, kas tai yra lyderystè. Atsižvelgiant ị mokslinéje literatūroje pateiktas lyderystès sampratos sąvokas, buvo atkilta turinio analizè. Buvo išskirtos penkios subkategorijos pagal šiuos reikšminius vienetus: vadovavimas, pasekejjai, itakojimas, asmeninès savybès, bendras tikslas. Respondentai noriai atsakinejo ir ị atvirą klausimą atsakè 98,2 proc. $(\mathrm{N}=171)$ respondentų. Iš tų, kurie atsakè ị ši klausimą, 23,3 proc. $(\mathrm{N}=40)$ lyderystès apibrezžime nepaminėjo né vieno iš penkių išskirtų reikšminių vienetų „,etikečių“. 2 lentelèje pa-

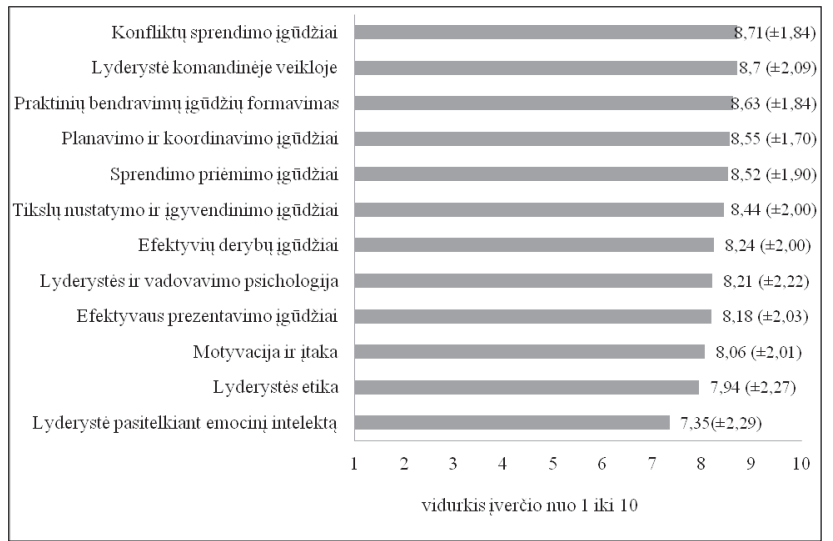

2 pav. Respondentų nuomonės pasiskirstymas pagal nurodytas lyderystès dalyko temas $(\bar{x})$

Pastaba: $\bar{X}$ - vidurkis. Kuo didesnè vidurkio reikšmè, tuo tema svarbesnè, kadangi koduota nuo 1 iki 10, kai 1 - visiškai nesvarbu ir 10-labai svarbu

teikti duomenys iliustruoja VSBS programos studentų supratimą apie lyderystès sąvoką. Buvo nustatyta, kad 76,6 proc. $(\mathrm{N}=131)$ respondentų lyderystès sąvokai apibrèžti panaudojo bent vieną iš penkių reikšminių vienetų. Taip pat rezultatai atskleide, kad 32,1 proc. būsimų visuomenès sveikatos specialistu lyderystę tapatino su vadovavimu ir 13,7 proc. asmeninèmis savybèmis, gebejjimais. Lyderystei apibrěžti taip pat dažnai buvo paminèta „etikečių“ kombinacija, kurioje naudojami reikšminiai vienetai - „vadovavimas“ ir „pasekejai““ (16,8 proc.). Buvo pateiktos devynios reikšminių vienetų kombinacijos, kuriose lyderystė netapatinama su vadovavimu, tokios kombinacijos buvo paminètos 16 kartu (12,5 proc.).

Siekiant ịvertinti VSBS programos studentų nuomonę apie lyderystès svarbą VS specialisto profesinèje veikloje, buvo pateikti teiginiai apie lyderystès ịgūdžių svarbą (1 pav.) ir prašoma respondentų išreikšti nuomonę pažymint skalèje nuo 1 iki 5, kur 1 - visiškai nesutinku, o 5 - visiškai sutinku. Rezultatai atskleidè, kad dauguma tiriamujjų teigiamai vertino lyderystès ịgudžių lavinimą ir manè, kad lyderystės igūdžių lavinimas praverstų visuomenès sveikatos specialisto praktineje veikloje.

Tyrimas parodè, kad 53,4 proc. ( $\mathrm{N}=93)$ studentų neturèjo studiju programoje lyderystès dalyko, o likusieji 46,6 proc. $(\mathrm{N}=81)$ susipažinę su lyderyste, nes jų studijų programoje yra pasirenkamas lyderystės dalykas arba lyderystès tema analizuojama kitų dalykų (modulių) metu. Iš tų, kurie neturèjo lyderystès dalyko savo studiju programoje, daugiau kaip pusè $(54,8$ proc.) noretų, jog i jų studijų programą būtu įtrauktas lyderystès dalykas. Ir tik 3,2 proc. nurodè nenorintys lyderystès dalyko studijų programoje (3 lentelè).

Dauguma (55,2 proc.) VSBS programos studentų manè, kad lyderystès dalykas turètų būti privalomas, o 37,9 proc. manè, jog lyderystės dalykas turètų būti pasirenkamas. Li- 
kusioji dalis $(6,9$ proc.) apklaustųjų nemanè, kad toks kursas apskritai yra reikalingas (4 lentelè).

Taip pat norejome sužinoti VSBS programos studentų nuomonę, kokios temos būtų labiausiai pageidaujamos lyderystės užsièmimų metu ir kas turètų vesti šiuos užsièmimus. Kaip matyti 2 paveiksle, iš pateiktų dvylikos galimų temų, skirtų lyderystès mokymui, VSBS programų studentai labiausiai norètų, jog ị lyderystès mokymus būtų ịtrauktos šios temos: „Konfliktų sprendimo ịgūdžiai“, „Lyderystè komandineje veikloje“, „Praktinių bendravimo ịgūdžių formavimas".

Tyrimo rezultatai atskleide, jog dauguma respondentu manè, kad lyderystès turètų mokyti dèstytojas, turintis vadovavimo patirti, ir visuomenès sveikatos lyderis (atitinkamai 51,1 proc. ir 42,0 proc.). Tik keli tiriamieji kaip galimus lyderystès dèstytojus paminejjo visuomenès sveikatos specialistą ir dèstytoją, neturintị vadovavimo patirties (atitinkamai 4,0 proc. ir 0,6 proc.).

\section{IŠVADOS}

Tyrimas atskleide, kad Lietuvos visuomenés sveikatos studentai teigiamai žiūri ị lyderystę visuomenès sveikatoje. Taip pat jie norètų studijuoti lyderystès kursą. Šis tyrimas ir jo rezultatai dar kartą parodè, kad lydersytė tampa vis svarbesniu reiškiniu visuomenès sveikatoje, todèl jai diegti visuomenès sveikatos organizacijose turètų būti skiriamas ypatingas dèmesys. Pats efektyviausias lyderystès igyvendinimo kelias būtų „lyderystès kultūros“ diegimas. Šios kultūros kūrimui galètų pasitarnauti ne tik esamų, bet ir būsimų visuomenès sveikatos specialistų lyderystės mokymas.

Literatūra

1. Grabauskas V., Kalėdienė R., Valius L. Visuomenès sveikatos mokslas ir studijos: atsakas ị laikmečio iššūkius. Kaunas: KMU leidykla, 2005

2. Jurkuvènas V. Visuomenès sveikatos specialistų kompetencija ir pasirengimas naujiems iššūkiams: Nacionalinès sveikatos tarybos metinis pranešimas. Vilnius, 2010; 69-71.

3. Kalėdienè R., Ščeponavičius A. Visuomenès sveikatos specialistų vaidmuo atsiliepiant ị sveikatos sistemos reformos iššūkius. Nacionalinès sveikatos tarybos metinis pranešimas 2006. Žmonių ištekliai sveikatos priežiūroje. Vilnius, 2007; 41-44.

4. Noreen MC, Weist E. Mastering the New Public Health. American Journal of Public Health 2000;90(8):1208.

5. Kalèdienė R, Ščeponavičius A, Kavaliūnas A, Ašoklienė L. Public health bureus: new players in health improvement in Lithuania. Acta Medica Lithuanica 2011;4(18):183-189.

6. Stankūnas M., Starkuvienė S., Kalėdienė R. Nuo visuomenės sveikatos specialistų link visuomenès sveikatos lyderių. Klaipėda: Klaipėdos universiteto leidykla, 2005; 9.

7. Kalèdienè R. Šiuolaikinès sveikatos vadybos svarba Lietuvos sveikatos sistemos reformos sėkmei. Medicina, 2004;40(9):891-896.

8. Rowitz L. Public health leadership. Putting Principles into Practice. Massachusetts. Jones and Bartlett publishers, 2003.

9. Umble K, Steffen D, Porter J, Miller D, Hummer-McLaughlin K, Lowman A, Zelt Z. The National Public Health Leadership Institute: Evaluation of a Team - Based Approach to Developing Collaborative Public Health Leaders. American Journal of Public Health 2005;95(4):641-644.
10. Šimanskienė L. Research on Personal Qualities Needed for Manager/Leader in the Time of Transformations. Klaipeda, Tiltai 2005; (1):2936 .

11. Savanevičienė A., Stukaitė D., Šilingienė V. Development of strategic individual competences. Inžinerinè ekonomika-Engineering economics, 2008; 3:81-88.

12. Šilingienė V. Lyderystès kompetencijos raiška individualios karjeros kontekste. Ekonomika ir vadyba, 2011; 16:961-968.

13. The new European policy for health - Health 2020: vision, values, main directions and approaches. WHO [Online] 2011. [cited 2012 March 30]. Available from: <http://www.euro.who.int/_data/assets/pdf file/0007/147724/wd09E Health2020 111332.pdf $>$.

14. Key components of a well functioning health system. WHO, [Online] 2010. [cited 2012 March 30]. Available from: <http://www.who.int/ healthsystems/EN HSSkeycomponents.pdf>.

15. Baronienė D. Lyderystė kaip švietimo organizacijos efektyvaus valdymo prielaida: magistro diplominis darbas. Šiauliai: Šiaulių universitetas, 2008

16. George B. Tiktoji kryptis: kaip tapti tikruoju lyderiu. Kaunas: UAB ,Smaltija“" 2008.

17. Herbst THH, Condradie PDP. Leadership effectiveness in Higher Education: Managerial self-perceptions versus perceptions of others. Journal of Industrial Psychology 2011;37(1):1-14.

18. Higgs $M$. How can we make sense of leadership in the $21^{\text {st }}$ cent tury? Leadership \& Organization Development Journal 2003; 24(5): 273-284.

19. Paccaud F, Weihofen A, Nocera S. Public health education in Europe: old and new challenges. Public Health Reviews. 2011;33:66-86.

20. Uno H, Zakariasen K. Public health leadership education in North America. Journal of Healthcare Leadership 2010;2:11-15.

21. Urbaitienė O., Kanapeckienė V., Valintėlienė R. Visuomenès sveikatos specialistų rengimo Lietuvoje ir Europoje vertinimas. Visuomenès sveikata, 2011; 4(55):56-65.

\section{LEADERSHIP IN PUBLIC HEALTH STUDY PROGRAMS:}

RESULTS FROM LITHUANIAN PUBLIC HEALTH STUDENTS SURVEY

Vitalija Zajančkauskienè, Mindaugas Stankūnas

Summary

Key words: public health specialist, competences, leadership.

The aim of the study was to evaluate the attitudes of public health undergraduate students regarding the need of leadership training. Methog dology. The cross sectional survey was carried out in the year 2011. The questionnaires has been distributed to all public health undergraduate students ( $3^{\text {rd }}$ and $4^{\text {th }}$ year) from Lithuanian University of Health Sciences, Vilnius University and Klaipeda University $(N=187)$. Response rate was 93\%. The anonymous questionnaires included both multiple-choice and open-ended questions. Results: The findings suggested that undergradug ate public health students were interested to study leadership. More than a half (53.4\%) of students responded that they do not have leadership course in their study programmes. More over, 54.9\% of them expressed the will to have it. Majority (86.6\%) of students were convinced that public health leadership skills are necessary for modern public health specialists; $63.8 \%$ considered that leadership training is the same importance as development of competences in public health area. Conclusions: The undergraduate public health students agreed that leadership skills are necessary in public health practice. Majority of students has expressed the will to have leadership training in their public health studies.

Correspondence to: mindstan@gmail.com

Gauta 2012-06-15 